\title{
THE IMPACT OF LIFE VALUES ON ENTREPRENEURIAL INTENTIONS OF STUDENTS IN SERBIA
}

UDC: 005.961:005.914.3:[17.022-057.875(497.11)

Original Scientific Paper

\author{
Milan NIKOLIĆ ${ }^{1}$, Dragan ĆOĆKALO ${ }^{1}$, Edit TEREK ${ }^{2}$, Sanja BOŽIĆ $^{3}$, \\ Aleksandra NASTASIĆ ${ }^{4}$ \\ ${ }^{1}$ University of Novi Sad, Technical Faculty “Mihajlo Pupin” Zrenjanin, 23000 Zrenjanin, Đure Đakovića bb, \\ Republic of Serbia \\ ${ }^{2}$ University of Novi Sad, Technical Faculty “Mihajlo Pupin” Zrenjanin, 23000 Zrenjanin, Đure Đakovića bb, \\ Republic of Serbia \\ E-mail: edit@tfzr.uns.ac.rs \\ ${ }^{3}$ University of Novi Sad, Faculty of Science, Department of Geography, Tourism and Hotel Management, 21000 \\ Novi Sad, Trg Dositeja Obradovića 6, Republic of Serbia \\ ${ }^{4}$ Belgrade Polytechnic, 11000 Belgrade, Brankova 17, Republic of Serbia
}

Paper received: 03.05.2017.; Paper accepted: 01.06.2017.

\begin{abstract}
In this study, the relationship between life values, the enterprise potential and the entrepreneurial intentions were researched. The survey was conducted in Serbia, and the respondents were students. A total of $\mathbf{3 8 0}$ valid questionnaires were collected. For the data processing, the following statistical methods were used: descriptive statistics, correlation and regression analysis. The main research results are as follows: 1 . Correlations between life values items and enterprise potential dimensions and entrepreneurial intentions dimensions, for the most part are not statistically significant, but there is also a significant number of correlations that are positive and statistically significant. The most powerful, significant and positive correlation achieve the following life values dimensions: LV3 - Self actualization, then LV5 - Love and affection. 2. The regression analysis indicates the presence of a statistically significant predictive effect of certain life value dimensions on the dimensions of enterprise potential and entrepreneurial intentions. Predictive effect is not so strong, but it is present at certain life value dimensions: LV3 - Self actualization and LV5 - Love and affection. These are the same dimensions having the strongest correlations, so it can be said that the results of these two analyses are consistent. 3. Dimension EI - Entrepreneurial intention has a statistically significant and positive correlation with the following dimensions of life values: LV5 - Love and affection, LV3 - Self actualization and LV2 - Personal gratification. 4. Individuals may examine their own life values, and on that basis examine their opportunities and potentials for entrepreneurial ventures. They can also implement appropriate adjustments in their value system, if they choose to run their own business.
\end{abstract}

Keywords: Life values, Enterprise potential, Entrepreneurial intentions, Students, Serbia.

\section{INTRODUCTION}

Entrepreneurship has a broad social significance, contributes to reducing unemployment and increasing the standard of people. In this way, entrepreneurship significantly raises the level of total national wealth (Miller, 2015). Entrepreneurs are people who are in the center of all activities related to the promotion of entrepreneurship, both at the individual and at the national level. Therefore, it is necessary to give attention to entrepreneurs, to encourage them and provide them with necessary support, in a systematic and socially responsible manner.

Among other things, to undertake entrepreneurial ventures, entrepreneurs need motivation. In the reference (Carsrud \& Brännback, 2011) the importance of entrepreneurial motivation for entrepreneurial intentions, and then for entrepreneurial behavior is emphasized. In relation to managers, entrepreneurs exhibit a higher level of 
motivation for achievement, which can be explained by the entrepreneur's venture goals (Stewart Jr. \& Roth, 2007).

The gender of entrepreneurs has an impact on the motivation and desire for achievement. Thus, male entrepreneurs show a significantly higher career / achievement orientation than men who are not entrepreneurs. At women, these differences are not statistically significant (DeMartino, Barbato, \& Jacques, 2006). In addition, a significant role in entrepreneurship have emotions of entrepreneurs. In the reference (Delgado-García, RodríguezEscudero, \& Martín-Cruz, 2012) the impact of emotions on setting targets for entrepreneurs was investigated. Positive affective traits affect entrepreneurs so that an entrepreneur sets broad and ambitious goals, and opposite, negative affective traits affect entrepreneurs so that he/she sets small goals.

Socio-cultural attributes, such as family value, goals and motivation for private business, significantly affect the performance at work (Toledo-López, Díaz-Pichardo, JiménezCastañeda, \& Sánchez-Medina, 2012). Entrepreneur's native culture has a direct impact on some salient values. However, entrepreneurs share certain core values, regardless of cultural origin (Morris \& Schindehutte, 2005).

The life values of individuals may help explain the impact on entrepreneurial intentions which is of particular interest for this work. Values and motivation can have a stimulating role in the movement from intention to action. They can also be important to overcome obstacles in the process of starting a business venture (Fayolle, Liñán, \& Moriano, 2014).

When the entrepreneurial venture has already begun and it lasts some time, entrepreneur's values are not linked to the success of a new venture, but they are important for improving firm performance (Tomczyk, Lee, \& Winslow, 2013). The most important criteria for success at the Dutch entrepreneurs are personal satisfaction, profitability and satisfied stakeholders (Gorgievski, Ascalon, \& Stephan, 2011). Values such as power and achievement contribute to achieving business growth, profitability and innovativeness. Values such as benevolence and universalism contribute to stakeholders satisfaction and good work-life balance, (Gorgievski et al., 2011).
Keeping in mind the above mentioned, it is clear that research in the field of entrepreneurship has a wider social and national significance. Therefore it is very important to explore the different influences on the existence and development of entrepreneurial intention and entrepreneurial behavior. The aim of this study is to discover the nature and strength of the relation between life values and the enterprise potential and the entrepreneurial intentions. The survey was conducted in Serbia, and the respondents were students. Additional importance of this research is that there are not many similar studies in the world.

\section{THEORY AND HYPOTHESIS}

\section{Life values}

Values indicate a strong belief that it is "a certain pattern of behavior or the final state of being personally or socially more desirable than the opposite way of behavior" (Rokeach, according to Robbins and Judge (2009)). Accordingly, the values are determined conditions and / or behavior, which we consider as preferred and proper. Values show what it is that people find good and what is considered to be bad (Janićijević, 2008).

Values have their content and intensity. The content of values shows what behaviors and conditions are good and important, while the intensity of values indicates the degree to which certain behaviors and states are good and important. When the values of a person are lined by the intensity (strength, importance) the value system of that person is given, (Robbins \& Judge, 2009). Value system is mostly formed in early childhood and is relatively stable over time.

Generally, the values are the basis for understanding and predicting the attitudes, motivation and behavior of people. Therefore, values are of great importance for understanding and studying of behavior in organizations. Also, it is not difficult to assume that there are certain influences of individual values on their entrepreneurial potential and entrepreneurial intentions.

\section{Enterprise potential and entrepreneurial intention}

Enterprise potential means a potential tendency for a person to start an entrepreneurial venture and become an entrepreneur. That still does not 
indicate the existence of a determined intention that the person really wants to become an entrepreneur and that he/she will become an entrepreneur. Enterprise potential only indicates that a person has the qualities and attitudes that contribute to launching entrepreneurial ventures. According to Athayde (2009), enterprise potential is a topic in the field of entrepreneurship, which is important and often investigated. In this paper, enterprise potential is measured through a questionnaire that was developed.

Entrepreneurial intention signifies the desire and readiness for starting entrepreneurial ventures. Therefore, entrepreneurial intentions have a major impact on the decision about starting own business, (Liñán \& Chen, 2009). Since the desire and motivation to start one's own business is often critical in this process, knowledge of entrepreneurial intentions is of great importance. This creates prerequisites for the development and emergence of a large number of entrepreneurs, which certainly has social significance. The key is that, through the development of entrepreneurial intentions at individuals, it is possible to systematically and deliberately affect the increase in the number of entrepreneurs. In this way the positive effect on society as a whole can be realized, so the study of entrepreneurial intention is of great importance. In this paper, entrepreneurial intentions were measured through entrepreneurial intention questionnaire (EIQ), (Liñán \& Chen, 2009).

On the basis of the previous exposure, the following hypotheses were set:

H1: There are significant positive correlations between certain life values dimensions and dimensions of enterprise potential.

H2: There are significant positive correlations between certain life values dimensions and dimensions of entrepreneurial intentions.

H3: There is a statistically significant predictive effect of life values dimensions (independent variable) on the dimensions of enterprise potential and dimensions of entrepreneurial intentions (dependent variable).

\section{METHODOLOGY}

\section{Survey instruments}

Life values For the measurement of life values, the RVS questionnaire was used (Rokeach Value Survay), which was developed by Milton Rokeach (according to Robbins (2003)). The questionnaire has eighteen items. These items present the most extreme values and refer to a preferred final state of existence (Robbins \& Judge, 2009). These are the values which an individual aspires to. Respondents evaluated each item ranging from 1 to 5. For the purposes of this study, these eighteen items were arranged in six factors (dimensions), the way it is defined in the reference (RabotegŠarić, Šarić, \& Zajc, 1997). The dimensions and items which make them are as follows (RabotegŠarić, Šarić, \& Zajc, 1997):

LV1 - Social harmony (A world of peace, Equality, Freedom, National security, Salvation).

LV2 - Personal gratification (A comfortable life, An exciting life, Pleasure, Social recognition, A sense of accomplishment).

LV3 - Self actualization (Wisdom, A world of beauty, Self respect, A sense of accomplishment, Inner harmony).

LV4 - Security (Salvation, Family security).

LV5 - Love and affection (An exciting life, True friendship, Mature love).

LV6 - Personal contentedness (Freedom, Happiness).

Enterprise potential Enterprise potential was measured by the Attitude Toward Enterprise questionnaire (ATE) Test, (Athayde, 2009). The questionnaire has 18 items distributed in 4 dimensions. The respondents evaluated each item ranging from 1 to 7 . The dimensions are as follows: 1. Leadership (LEA), 2. Creativity (CRE), 3. Achievement $(\mathrm{ACH})$ and 4. Personal control (PC).

Entrepreneurial intentions. Entrepreneurial intentions were measured using the Entrepreneurial Intention Questionnaire (EIG), (Liñán \& Chen, 2009). The questionnaire has 20 items distributed in 4 dimensions. The respondents evaluated each item ranging from 1 to 5 . In this study, we used the following three aspects: 1. Subjective norm (SN), 2. Perceived behavioral control (PBC) and 3 . Entrepreneurial intention (EI).

\section{Participants and data collection}

The subjects were students from five faculties in Serbia. The students from first to fifth year of study were surveyed. The questionnaires were anonymous, and the survey was conducted during the teaching hours. A total of 380 valid questionnaires were collected. The surveyed 
students were between 18 and 27 years of age. In addition, the sample included 237 female and 143 male students.

\section{RESULTS}

\section{Descriptive Statistics}

Descriptive statistics for the life values dimension is given in Table 1. The first impression is that all the items have a high average value, respectively that students highly value the listed life values.

\section{Correlation analysis}

Correlation analysis was performed between life values dimensions and the dimensions of enterprise potential and dimensions of entrepreneurial intentions. Pearson Correlation was used. Results of thus performed correlation analysis are given in Table 2.

\section{Regression analysis}

Through Multuple Regression Analysis the predictive effect of life values was determined on the dimensions of enterprise potential and dimensions of entrepreneurial intentions. Life values dimensions present the independent variable, and the dimensions of enterprise potential and dimensions of entrepreneurial intentions are the dependent variable. The results of regression analysis are presented in Table 3.

Table 1: Descriptive statistics

\begin{tabular}{|l|c|c|c|c|c|c|c|}
\hline \multicolumn{1}{|c|}{ Items name } & $\begin{array}{c}\text { Short } \\
\text { name }\end{array}$ & $\mathbf{N}$ & Min & Max & Mean & Std. Dev. & $\begin{array}{c}\text { Cronbach's } \\
\text { Alpha }\end{array}$ \\
\hline Social harmony & LV1 & 380 & 1.50 & 5.00 & 4.2480 & .68855 & .715 \\
\hline Personal gratification & LV2 & 380 & 2.00 & 5.00 & 4.2184 & .63146 & .714 \\
\hline Self actualization & LV3 & 380 & 1.80 & 5.00 & 4.3784 & .57149 & .768 \\
\hline Security & LV4 & 380 & 1.50 & 5.00 & 4.2961 & .74693 & .704 \\
\hline Love and affection & LV5 & 380 & 2.00 & 5.00 & 4.4632 & .60107 & .705 \\
\hline Personal contentedness & LV6 & 380 & 2.50 & 5.00 & 4.7211 & .49784 & .708 \\
\hline \multicolumn{1}{|c|}{ Valid N (list) } & & 380 & & & & & \\
\hline
\end{tabular}

Table 2: Pearson coefficients of correlation between life values dimensions and the dimensions of enterprise potential and dimensions of entrepreneurial intentions

\begin{tabular}{|l|c|c|c|c|c|c|c|}
\hline \multicolumn{1}{|c|}{} & LEA & CRE & ACH & PC & SN & PBC & EI \\
\hline LV1 - Social harmony & -.032 & $.224^{* *}$ & .021 & .021 & .072 & .030 & .027 \\
\hline LV2 - Personal gratification & .012 & $.206^{* *}$ & $.115^{*}$ & -.005 & .037 & .086 & $.125^{*}$ \\
\hline LV3 - Self actualization & $.109^{* *}$ & $.356^{* *}$ & $.156^{* *}$ & $.128^{*}$ & $.111^{*}$ & .090 & $.102^{*}$ \\
\hline LV4 - Security &. .036 & $.110^{*}$ & -.011 & .017 & .037 & .035 & .048 \\
\hline LV5 - Love and affection & .077 & $.273^{* *}$ & $.188^{* * *}$ & .100 & .016 & $.107^{*}$ & $.112^{*}$ \\
\hline LV6 - Personal contentedness & .015 & $.258^{* *}$ & .071 & .026 & $.121^{*}$ & .038 & .059 \\
\hline
\end{tabular}

* Correlations significant at level 0.01

** Correlation significant at level 0.05

Table 3: Regression analysis (Independent Variable: life values dimensions, Dependent Variable: dimensions of enterprise potential and dimensions of entrepreneurial intentions)

\begin{tabular}{|c|c|c|c|c|c|c|c|c|c|}
\hline \multirow{3}{*}{ Dep. } & \multicolumn{6}{|c|}{ Independent } & \multirow{3}{*}{$\mathbf{R}^{2}$} & \multirow{3}{*}{$\mathbf{F}$} & \multirow{3}{*}{ Sig. } \\
\hline & LV1 & LV2 & LV3 & LV4 & LV5 & LV6 & & & \\
\hline & \multicolumn{6}{|c|}{$\beta$} & & & \\
\hline LEA & $-.207 * *$ & -.092 & $.201 *$ & .011 & .090 & -.052 & .042 & 2.726 & .013 \\
\hline CRE & .025 & -.035 & $.320 *$ & -.117 & .114 & .038 & .140 & 10.145 & .000 \\
\hline ACH & -.110 & -.025 & $.201 * *$ & -.073 & $.195^{* *}$ & -.059 & .059 & 3.926 & .001 \\
\hline $\mathbf{P C}$ & -.139 & $-.205^{* *}$ & $.249 * *$ & .058 & $.180^{* *}$ & -0.73 & .047 & 3.073 & .006 \\
\hline SN & -.53 & .23 & .141 & -.001 & -.137 & .126 & .026 & 1.469 & .133 \\
\hline PBC & -.79 & .018 & .106 & .018 & .082 & -.046 & .016 & 1.034 & .403 \\
\hline EI & -.152 & .102 & .133 & .048 & .008 & -0.13 & .025 & 1.570 & .155 \\
\hline
\end{tabular}

$* \beta$ coefficients significant at level 0.01

$* * \beta$ coefficients significant at level 0.05 


\section{DISCUSSION}

The results of the descriptive statistics (Table 1) show high average scores for all observed dimensions of life values. This should take into account that all the items of life values were important for most people, so these results can be considered as expected. However, one can point out dimensions with the highest and lowest average scores. The highest average ratings have dimensions LV6 - Personal contentedness (4.7211), then LV5 - Love and affection (4.4632). These values may be considered as largely universal, so this result is logical. Thus, students highly value items such as: Freedom, Happiness, Mature love, true friendship. In contrast, the lowest average marks achieved the following dimensions: LV2 - Personal gratification (4.2184), LV1 - Social harmony (4.2480). These dimensions also have high average marks, but compared to other life value dimensions, students consider them less important. This particularly applies to the item Salvation, probably because the item contains certain aspects of unreality.

Table 2 shows the results of correlation analysis. Generally, in most cases, the correlations were not statistically significant. Nevertheless, in the same time, there is a significant number of correlations that are positive and statistically significant. These correlations are concentrated around a few dimensions of life values and several dimensions of enterprise potential and entrepreneurial intentions. Based on these results, we can say that the hypothesis $\mathrm{H} 1$ and $\mathrm{H} 2$ are partially confirmed, ie., hypotheses $\mathrm{H} 1$ and $\mathrm{H} 2$ are confirmed for some dimensions of life values.

From life values dimensions, most powerful, statistically significant correlations generate LV3 Self actualization, then LV5 - Love and affection. Obviously, the desire and need for achievement and accomplishment, wisdom, self respect and the pursuit of exciting life are the motives that are conducive to enterprise potential and entrepreneurial intentions. Such people have a strong motive to achieve something in life, to have an exciting life. At the same time, there is a recognition that these goals can in the easiest and fastest way be achieved through starting one's own business which can be risky, but offers the highest possible earnings, if successful. It should be noted that one of the items of the dimensions LV3 - Self actualization the item Knowledge and wisdom (mature understanding of life). In fact, it is the knowledge and wisdom that is needed for successful designing, launching and running an own business. Only if it is driven by knowledge and wisdom, business can be successful, and only a successful business provides earnings and all other previously explained motives (especially aspirations for achievement and exciting life). Thus, these results actually are logical, and students show maturity when at the same time highly value knowledge and wisdom, as well as their entrepreneurial potential and intentions.

From enterprise potential dimensions and entrepreneurial intentions dimensions, by far the most powerful, statistically significant correlations occur at dimensions CRE - Creativity. Apparently, the high life values indicate a creative person. This result can be interpreted in the opposite direction: creative people have high life values. Creative people recognize their potential, and this gives them the right to seek for a broader spectrum (content) of life values with high intensity. Also, strong and statistically significant correlations occur with dimensions ACH - Achievement and EI - Entrepreneurial intention. Some life values dimensions (primarily LV5 - Love and affection, LV3 - Self actualization and LV2 - Personal gratification) positively affect the dimension $\mathrm{ACH}$ - Achievement. These life value dimensions encourage the desire and need for achievement. Similarly, the dimension EI - Entrepreneurial intention is positively affected by the same life values dimensions (LV5 - Love and affection, LV3 - Self actualization and LV2 - Personal gratification). The presence and high intensity of these life value dimensions encourage entrepreneurial intentions.

The results of regression analysis (Table 3) indicate that, in certain cases, there is a statistically significant predictive effect of certain life values dimensions on the enterprise potential dimensions and the entrepreneurial intentions dimensions. The values of the corrected determination indices $R^{2}$ are not so large and are in the range of 0.016 to 0.140 . Based on these results, it can be concluded that the hypothesis $\mathrm{H} 3$ is partially confirmed. There still should be noted that the amount of the value of the corrected determination index $R^{2}$, at individual dimensions of enterprise potential and entrepreneurial intentions, is such that it points to the consistency of these results with the results of correlation analysis. Also, the results are consistent 
with the results of the correlation analysis if we observe life value dimensions which have the strongest predictive effect. As with correlation analysis, these are the following dimensions: LV3 Self actualization and LV5 - Love and affection.

However, viewed individually for each dimension of enterprise potential and entrepreneurial intentions, the results of regression analysis showed some differences in relation to the results of correlation analysis. Thus, for example, on the dimension LEA - Leadership - the dimension LV1 - Social harmony has a statistically significant negative predictive effect. People with leadership qualities and preferences, logically, do not attach particular importance to values such as equality, world peace, and salvation. Further, the dimension LV2 - Personal gratification has a strong statistically significant negative predictive effect on the dimension PC - Personal control. This can be explained in the way that the dimension LV2 Personal gratification make up items, such as A comfortable life, An exciting life, Pleasure, and these items indicate a certain degree of relaxation and the potential lack of desire to independently undertake certain activities.

\section{CONCLUSION}

Average marks of life value dimensions are high, mostly for the following dimensions: LV6 Personal contentedness and LV5 - Love and affection. This result can be considered as expected.

Correlations between life values dimensions and enterprise potential dimensions and entrepreneurial intentions dimensions, for the most part are not statistically significant, but there is also a significant number of correlations that are positive and statistically significant. The most powerful, significant and positive correlations achieve the following life value dimensions: LV3 - Self actualization, then LV5 - Love and affection.

The regression analysis indicates the presence of a statistically significant predictive effect of certain life value dimensions on the dimensions of enterprise potential and entrepreneurial intentions. Predictive effect is not so strong, but it is present at certain life value dimensions: LV3 - Self actualization and LV5 - Love and affection. The consistency with the results of correlation analysis is obvious.
Given the importance of the dimension EI Entrepreneurial intention, it should be noted that this dimension has a statistically significant positive correlation with the following dimensions of life values: LV5 - Love and affection, LV3 Self actualization and LV2 - Personal gratification.

These results are important for better understanding of the impact of life values on the enterprise potential and entrepreneurial intentions. The importance is even greater if one takes into account that there is just a few research on this topic around the world. The practical implication of the results is that individuals can examine their own life values, and on that basis examine their opportunities and potentials for entrepreneurial ventures. Of course, the results of this, individual, personal analysis may not be crucial for the final decision to start one's own business, but it certainly can point to certain positive and negative impacts on readiness for entrepreneurship and success of future work. Also, individuals can learn about themselves and implement appropriate corrections in their value system, if they choose to run their own business.

\section{ACKNOWLEDGEMENT}

This paper is a result of the research activities conducted under the project "Improving the entrepreneurial climate, analysis of aspects and possible plans of action of young people in the Region of Central Banat", which is financed by the Provincial Secretariat for Higher Education and Scientific Research of Autonomous Province of Vojvodina, Republic of Serbia.

\section{REFERENCES}

Athayde, R. (2009). Measuring Enterprise Potential in Young People. Entrepreneurship Theory and Practice, 33(2), 481-500.

Carsrud, A., \& Brännback, M. (2011). Entrepreneurial Motivations: What Do We Still Need to Know? Journal of Small Business Management, 49(1), 9-26.

Delgado-García, J.B., Rodríguez-Escudero, A.I., \& Martín-Cruz, N. (2012). Influence of Affective Traits on Entrepreneur's Goals and Satisfaction. Journal of Small Business Management, 50(3), 408428.

DeMartino, R., Barbato, R., \& Jacques, R.H. (2006). Exploring the Career/Achievement and Personal Life Orientation Differences between Entrepreneurs and Nonentrepreneurs: The Impact of Sex and Dependents. Journal of Small Business Management, 44(3), 350-368. 
Gorgievski, M.J., Ascalon, M.E., \& Stephan, U. (2011). Small Business Owners' Success Criteria, a Values Approach to Personal Differences. Journal of Small Business Management, 49(2), 207-232

Fayolle, A., Liñán, F., \& Moriano, J.A. (2014). Beyond entrepreneurial intentions: values and motivations in entrepreneurship. International Entrepreneurship and Management Journal, 10(4), 679-689.

Janićijević, N. (2008). Organizational Behavior, Beograd: Data Status. (in Serbian)

Liñán, F., \& Chen, Y.W. (2009). Development and Cross-Cultural Application of a Specific Instrument to Measure Entrepreneurial Intention.

Entrepreneurship Theory and Practice, 33(3), 593617.

Miller, D. (2015). A downside to the entrepreneurial personality. Entrepreneurship Theory and Practice, 39(1), 1-8.

Morris, M., \& Schindehutte, M. (2005). Entrepreneurial Values and the Ethnic Enterprise: An Examination of Six Subcultures. Journal of Small Business Management, 43(4), 453-479.
Raboteg-Šarić, Z., Šarić, J., \& Zajc, M. (1997). A study of values among adolescents: assessing terminal and instrumental value systems and orientations. Social Issues, 6(32), 775-785.

Robbins, S.P., \& Judge, T.A. (2009). Organizational Behavior, 12th Edition, Zagreb: Mate d.o.o. (in Croatian)

Robbins, S.P. (2003). Organizational Behavior, Englewood Cliffs, N.J.: Prentice Hall Inc.

Stewart Jr., W.H., \& Roth, Ph.L. (2007). A MetaAnalysis of Achievement Motivation Differences between Entrepreneurs and Managers. Journal of Small Business Management, 45(4), 401-421.

Toledo-López, A., Díaz-Pichardo, R., JiménezCastañeda, J.C., \& Sánchez-Medina, P.S. (2012). Defining success in subsistence businesses. Journal of Business Research, 65(12), 1658-1664

Tomczyk, D., Lee, J., \& Winslow, E. (2013). Entrepreneurs' Personal Values, Compensation, and High Growth Firm Performance. Journal of Small Business Management, 51(1), 66-82.

\section{UTICAJ ŽIVOTNIH VREDNOSTI NA PREDUZETNIČKE NAMERE KOD STUDENATA U SRBIJI}

U ovom radu istražene su relacije između životnih vrednosti, preduzetničkog potencijala i preduzetničkih namera. Istraživanje je sprovedeno u Srbiji, a ispitanici su bili studenti. Ukupno je sakupljeno 380 validnih upitnika. Za obradu podataka korišćene su sledeće statističke metode: deskriptivna statistika, korelaciona i regresiona analiza. Osnovni rezultati istraživanja su sledeći: 1. Korelacije, između aspekata životnih vrednosti i dimenzija preduzetničkog potencijala i dimenzija preduzetničkih namera, većim delom nisu statistički značajne, ali istovremeno postoji i značajan broj korelacija koje su pozitivne i statistički značajne. Najsnažnije, statistički značajne i pozitivne korelacije ostvaruju sledeće dimenzije životnih vrednosti: LV3 - Samoostvarenje, potom LV5 - Ljubav i privrženost. 2. Regresiona analiza ukazuje na prisustvo statistički značajnog prediktivnog dejstva pojedinih dimenzija životnih vrednosti na dimenzije preduzetničkog potencijala i dimenzije preduzetničkih namera. Prediktivno dejstvo nije toliko snažno, ali postoji kod pojedinih dimenzija životnih vrednosti: LV3 - Samoostvarenje i LV5 - Ljubav i privrženost. To su iste dimenzije koje imaju najsnažnije korelacije, pa se može reći da su rezultati ove dve analize konzistentni. 3. Dimenzija EI - Preduzetničke namare ima statistički značajne i pozitivne korelacije sa sledećim dimenzijama životnih vrednosti: LV5 - Ljubav i privrženost, LV3 Samoostvarenje i LV2 - Lično zadovoljenje. 4. Pojedinci mogu ispitati sopstvene životne vrednosti i na bazi toga sagledati svoje mogućnosti i potencijale za preduzetnički poduhvat. Oni, takođe, mogu da sprovedu odgovarajuće korekcije u svom vrednosnom sistemu, ukoliko se opredele za pokretanje sopstvenog posla.

Ključne reči: Životne vrednosti, Preduzetnički potencijal, Preduzetničke namere, Studenti, Srbija. 